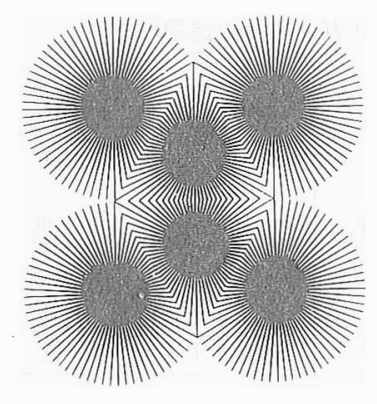

\title{
マイクロエレクトロニクスに おけるフォトリソグラフィー
}

\section{浅海 愼五}

Shingo Asaumi, 東京応化工業(株)

\section{1. はじめに}

半導体工業の発展はめざましく，集積回路 (IC) の 出現から四半世紀の間に LSI, 超 LSI へと集積度の 向上が進み， $1 \mathrm{M}$ ビット D-RAM の量産が開始され つつる。

集積度の向上はリソグラフィーの歴史であり，微細 加工の寸法も $1 \sim 16 \mathrm{k} \mathrm{LSI} の 10 \sim 5 \mu \mathrm{m}$ から $64 \mathrm{k}$ ビッ トでは $3 \mu \mathrm{m}, 256 \mathrm{k}$ ビットは $2 \mu \mathrm{m}, 1 \mathrm{M}$ ビットは 1.3 1.0 $\mu \mathrm{m}$ へと微細化して, 試作段階の $4 \mathrm{M}$ ビッ トは $0.8 \mu \mathrm{m}$ とサブミクロンに突入する.

半導体 IC 製造の初期リソグラフィーはフォトリソ グラフィーだけで, IBM の超 LSI 構想の発表された 1970 年にはフォトリソグラフィーの限界は $2 \mu \mathrm{m}$ と され，超 LSI 開発のために紫外線より波長の短い電 子線, X 線およU゙ Deep UV リソグラフィーについて レジスト材料を含めた開発が盛んに行なわれてきた。

フォトリソグラフィーはシリコンウェハなどの基板 に, フォトレジストを塗布, 乾燥, 露光, 現像の順に 処理してレジストパターンを形成し，これを保瀑膜と してエッチングなどの加工を行なう方法であり，一度 に多数の加工を行なうのに適している.

フォトレジストにはネが型とポジ型とがあり, 光に よって重合または橋かけするものをネが型, 光によっ て分解して現像液に溶解するものをポジ型と称してい る.

フォトリソグラフィーに用いる光源は $350 \sim 450 \mathrm{~nm}$ の波長の光で, 解像限界は $0.5 \mu \mathrm{m}$ 付近である. Deep UV リソグラフィーは $200 \sim 300 \mathrm{~nm}$ の光源を用 いて扔り，フォトリソグラフィーの延長として一部適 用されている。

電子線リソグラフィーは一括露光が難しく量産技術 には適さないが, 微細パターンの描画に適しており,

Photolithography for Micro-Electronics
すでにマスク製作に実用化されているＸ線リソグ ラフィーは一括転写が可能であり, 今後のリソグラフ イーとして超々 LSI の製作に有望視されているが, いまだに露光装置とマスクに問題がある。

本稿ではフォトレジスト材料を中心に動向について 述べ，さらに将来展望としてサブミクロン加工技術に ついて紹介する。

\section{2. フォトレジストの動向}

フォトリソグラフィーが半導体製造プロセスに採用 された当初においては，ネガ型フォトレジストの KPR (Kodak 社) が使用されてフォトリソグラフィ 一の確立がなされた，KPR は主成分をポリケイ皮酸

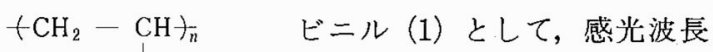
O
I
$\mathrm{C}=0$
CH
$\mathrm{CH}$
$\mathrm{CH}$
$\mathrm{CH}$ $(<350 \mathrm{~nm})$ が短いため, 堌感剂 を添加して露光用光源の超高圧 水銀灯の波長 $(350 \sim 450 \mathrm{~nm})$ に合うように増感させたもので ある。

（1）半導体製造プロセスに用いる フォトレジスト材料に要求される特性は,

1）目的とする光源の波長に合い, 感度が高いこと。

2）解像度が高く, パターンに蛇行やくびれのないこ と.

3）基板に対する密着性がよく，耐エッチング性の優

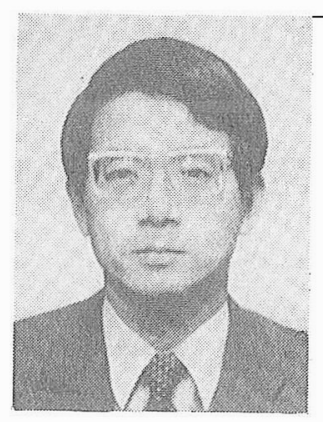

浅海惧五 東京応化工業(株) (253-01 神奈川県高座郡寒川町 田端 1590) SR 工場長 昭和 38 年日大理工学部工業化 学科卒. 43 年東京応化工業 (株) 入社, 現在に至る。半導体 IC 用フォトレジスト材料の開 発に従事.

〈趣味〉写真, 洋蘭 
表 1 LSI の集積度とリソグラフィーの変遷

\begin{tabular}{|c|c|c|c|c|}
\hline 年代 & LSIの集積度 & パターン寸法 & 露光装 置 & レジスト \\
\hline 1970 & $1 \mathrm{k}$ ビット & $10 \mu \mathrm{m}$ & コンタクトアライナー & ゴム系フォトレジスト \\
\hline 1973 & $4 \mathrm{k}$ & $8 \mu \mathrm{m}$ & コンタクトアライナー & ゴム系フォトレジスト \\
\hline 1976 & $16 \mathrm{k}$ & $5 \mu \mathrm{m}$ & コンタクトアライナー & ゴム系フォトレジスト \\
\hline 1979 & $64 \mathrm{k}$ & $3 \mu \mathrm{m}$ & $\begin{array}{l}\text { コンタクトアライイナー } \\
1: 1 \text { ミラープロジェクション }\end{array}$ & $\begin{array}{l}\text { ゴム樂フォトレジスト } \\
\text { ポシ型フォトレジスト }\end{array}$ \\
\hline 1982 & $256 \mathrm{k}$ & $2 \mu \mathrm{m}$ & 10 :1ステッパー $(N A 0.28)$ & ポジ型フォトレジスト \\
\hline 1985 & $1 \mathrm{M}$ & $1.3 \mu \mathrm{m}$ & 5：1ステッパー(NA 0.35) & ポジ型フォトレジスト \\
\hline 1988? & $4 \mathrm{M}$ & $0.8 \mu \mathrm{m}$ & $\begin{aligned} 5: & 1 \text { ステッパー } \\
& (N A \quad 0.35 \sim 0.42)\end{aligned}$ & ポジ型フォトレジスト \\
\hline $1991 ?$ & $16 \mathrm{M}$ & $0.5 \mu \mathrm{m}$ & 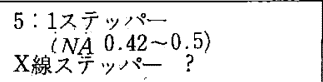 & $\begin{array}{l}\text { ポジ+CEL? } \\
\text { X線レジスト? }\end{array}$ \\
\hline
\end{tabular}<smiles>Nc1ccc(C=C2CCCC2=Cc2ccc(N)cc2)cc1</smiles>

(4)<smiles>CC1CC(=Cc2ccc(N)cc2)C(=O)C1=Cc1ccc([N])cc1</smiles>

(5)
れていること.

4）ピンホールやカケの少ないこと.

5）品質的に安定で経時変化がなく，ロット間バラツ キの少ないこと。

6）プロセス許容性の大きいこと.

7）デバイス特性に悪影響を及ぼす不純物を含まない こと.

8）耐薬品性および耐ドライエッチング性の優れてい ること.

9）安洒で入手しやすいこと。

などがあげられるが，ポリケイ皮酸ビニルはフォトレ ジスト膜での保存の安定性が悪く，安定で安価なゴム 系フォトレジストに置き換っている.

ゴム系フォトレジストは天然ゴムの主成分であるポ リイソプレンを環化した環化ゴム（2）と光橋かけ剂 であるビスアジド（3）をキシレンに溶解したもので ある。<smiles>CCC=C(C)CCCC1(C)CCCC1(C)CC</smiles>

$$
\mathrm{N}_{3}-\mathrm{R}-\mathrm{N}_{3}
$$

ゴム系フォトレジストは感度が高く, 密着性に優れ てウエットエッチングに対する耐性がよく，ピンホー ル密度が小さい，品質的に安定してプロセス許容性が 大きいので使いやすいが，現像液中での膨潤により解 像度は $2 \mu \mathrm{m}$ しかなく，表 1 に示すように $3 \mu \mathrm{m}$ 寸法 までの LSI 製造プロセス用フォトレジストの主流を なしていた。

ビスアジド類としては，2,6-ジ-(4-アジドベンジリ デン) シクロへキサノン（4）や2,6-ジー(4-アジドベ ンジリデン)-4-メチルシクロヘキサノン（5）が使用
されている。

ゴム系フォトレジストの現像液中での膨潤の問題か ら, 膨潤の少ない高解像度のアジド系ネガ型フォトレ ジストも開発されている。レジストしてはポリメチ ルイソプロペニルケトンービスアジド $(5)^{1)}$ やポリビ ニルフェノールーアジド $(6)^{2)}$, さらに長波長の光に 感じるようにアジド (7) 妾用いたものが報告されて いる。

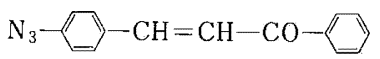

$$
\left.\mathrm{N}_{3}-\mathrm{W}+\mathrm{CH}=\mathrm{CH}\right)_{2} \geq \sum_{\mathrm{CH}_{3}}^{\mathrm{O}}
$$

ゴム系フォトレジストの光反応はビスアジドが紫外 線によって分解してナイトレンとなり，ナイトレンが 橋か㳡反応を行なう。

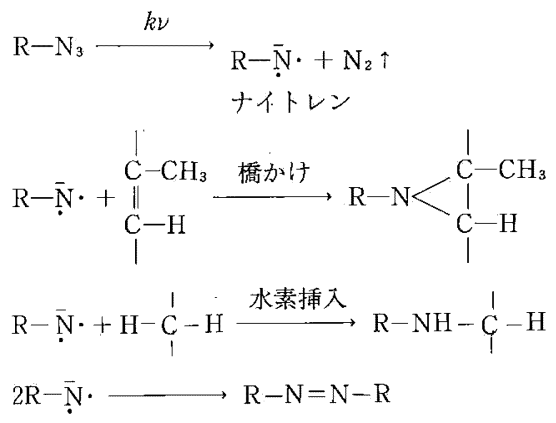

ポジ型フォトレジストはサブミクロンの解像は可能 であるが，密着露光でのレジストの欠けの発生とウ工 ットエッチングでのサイドエッチングが大きいため, 密着露光とウエットエッチングが主流の半導体 IC 製 造プロセスでは，アルミ配線など一部の工程でしか使 用されていなかった。

歩留り向上のためのプロジェクション露光法の普及 


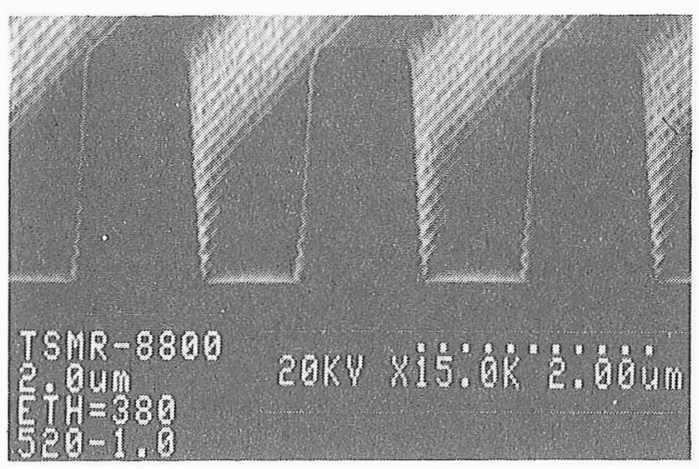

写真 1 ポシ型フォトレジストの断面形状 $(0.8 \mu \mathrm{m} L \times S)$

とドライエッチング法の発達によって, ポジ型フォト レジストの欠点が補われ，高解像性と耐ドライエッチ ング性が見直されて現在では超 LSI 製造用レジスト 材料の主流となっている．縮小投影露光装置（ステッ パーの発達によってサブミクロンパターンが得られ るようになっている. 写真 1 にポジ型フォトレジスト の断面形状を，写真 2 にウェットエッチングとドライ エッチングの比較を示す.

ポジ型フォトレジストは光分解剤のナフトキノンジ アジドスルホン酸エステル (8) とクレゾールノボラ ック樹脂（9）功構成されている.

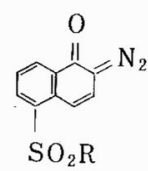

(8)<smiles>CCc1cc(C)ccc1O</smiles>

ナフトキノンジアジドスルホン酸エステルとしては クレヅールノボラック樹脂（10）, 没食子酸アルキル (11)，2，3，4-トリヒドロキシベンゾフェノン (12) な どのエステルが使用されている。

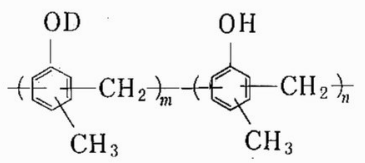<smiles>[R]OC(=O)c1cc([18O])c([18OH])c([18OH])c1</smiles>

(11)<smiles>[2H]OC1([2H])C=CC(C(=O)c2ccccc2)C1[2H]</smiles>

(12)<smiles>[R]=C1C=CC2=C(S(=O)(=O)[O-])C(=N)C=CC12</smiles>

$\mathrm{O}_{2}^{-}$
ポジ型フォトレジストに紫外線を照射すると, ナフ トキノンジアジド基が分解して分子内転位を起こし て, アルカリ現像液に可溶なインデンカルボン酸に変 わり，露光部のみが溶解する.

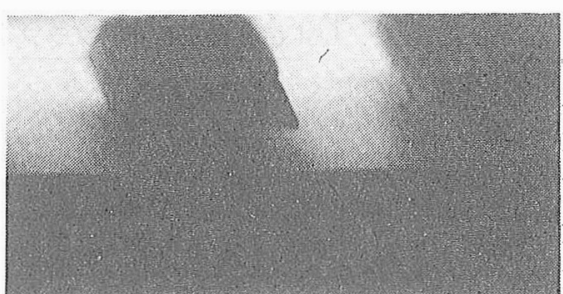

(a) ウェットエッチング

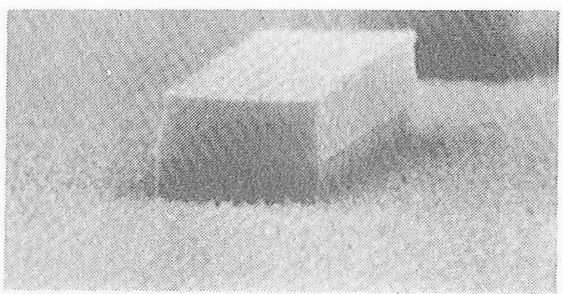

(b) ドライエッチング

写真 2 ウェットエッチングとドライエッ チングの比較（基板：Al）

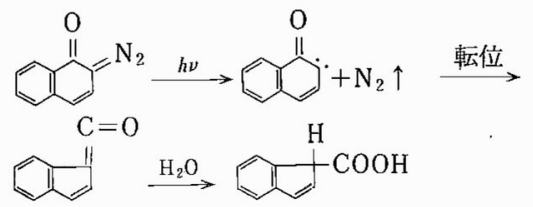

\section{3. サブミクロン加工技術および将来展望}

縮小投影露光におけるポジ型フォトレジストの解像 度 $L$ は波長を $\lambda$, ステッパーのレンズ開口数を $N A$ とすると次式で表わすことができる。

$L=k \lambda / N A$

露光用波長は $\mathrm{G}$ 線 $(436 \mathrm{~nm})$ が使用されており, $N A$ は 0.35 のものが生産に使用されている。 $k$ は 0.61 が可能であることから解像度は $0.76 \mu \mathrm{m}$ あり, $N A$ が 0.42 のレンズでは $0.63 \mu \mathrm{m}$ が解像できる. ᄂ かし $N A$ を大きくすると解像度は向上するが, 焦点 深度 $\delta$ は著しく浅くなる。

$$
\delta=\lambda / 2(N A)^{2}
$$

焦点深度からは高 $N A$ 化より波長の短波長化によ る解像度の向上の方が望ましく，I 線 $(365 \mathrm{~nm}$ ) を用 いたリソグラフィーも検討されている4).

サブミクロン領域では光の波長に近づくため, 光の 回折現象によるコントラストの低下と, 基板表面から の反射による定在波の影響がある、レジストのコント ラストを向上させる方法として，フォトレジストの表 面に CEL (Contrast Enhancement Layer) ${ }^{5)}$ と称子る 層をつくり，この層の消色効果によってコントラスト を向上させて高解像度を得た例が報告されている5). また基板からの反射に対しては，フォトレジスト層の 
下に反射防止層を形成する ARC (Anti Reflective Coating）が報告されている6.

半導体デバイスの表面は平担ではなく，特にアルミ 配線などの最終工程では段差の高低が $1 \mu \mathrm{m}$ 近くにま で達している。このような基板ではフォトレジストを 均一な厚さに塗布することは難しく，段差と直角に交 差するパターンではエッジの部分でくびれを生じて, 均一な寸法を得ることは難しい。この解決方法として 2 層および 3 層の多層レジスト法が報告されている7).

2 層レジスト法は, 基板に Deep UV レジストのポ リメチルメタクリレート (PMMA)を塗布して表面の 凹凸を埋めた後，ポジ型フォトレジストを塗布する PCM 法がある. PCM 法は紫外線露光, 現像によっ て，上層のポジ型フォトレジストパターンを形成し， これをマスクとして下層の PMMA 層を Deep UV 露 光, 現像する方法である. 3 層法は段差をポジ型フォ トレジストで埋めて平担化した後, 耐酸素プラズマ性 のよいシリコン酸化膜を形成し，その上にポジ型フォ トレジストを塗布する方法で，まず上層のポジ型フォオ トレジストを露光, 現像した後, 得られたパターンを 保護膜としてフッ素系の RIE (リアクティブイオンエ ッチング) でエッチングして，さらに下層のポジ型フ オトレジスト層を酸素 RIE でエッチングする方法で あるＰPCM 法は耐ドライエッチング性に， 3 層法は 工程が面倒という欠点がある。

これらの欠点老改良するため, 上層に耐ドライエッ チング性のよい無機系レジストを用いた 2 層レジスト 法が報告されている、レジスト材料としては含シリコ ンのものが多く ${ }^{8)}$, 感放射線反応基として Si-Si 結合 を有するレジストの報告もあるが，そのほとんどは従 来の電子線や紫外線反応基を利用したものである。

フォトリソグラフィーの解像限界は $0.5 \sim 0.6 \mu \mathrm{m}$ であるが，最近 NA 0.6 のレンズを用いて $0.4 \mu \mathrm{m}$ 以 下の解像度を得た例が報告されている9 . 光源につい てはエキシマレーザーを用いた Deep UV 光 $(222 \sim 308 \mu \mathrm{m})$ による露光も検討されている ${ }^{10)}$. さら に0.5 $\mu \mathrm{m}$ 以下の領域では電子線や X 線があるが, 電子線は一括照射ができないので量産技術には不向き である。したがって次期りソグラフィーとしては X 線リソグラフィーが有力である．X 線リソグラフィ 一は高コントラストの微細加工が可能, 一括転写によ ク高スループットが可能; 透過性がよいのでマスク上 のゴミなどの欠陥が転写されにくい，ウェ八表面の凹 凸に左右されずに微細パターンの形成が可能などの長 所 ${ }^{11}$ を有しており，実用化への検討が進妨らてい る.

$\mathrm{X}$ 線レジストとしては, 八ロゲン元素が $\mathrm{X}$ 線の吸
収がよいので含八ロゲンレジストが数多く報告されて いる。耐ドライエッチング性のよいレジストとしては ネが型の $\mathrm{CMS}^{12)} や \mathrm{CPMS}^{11)}$,などがある.

露光装置では X 線源として従来の衝撃型のものは 強度が弱く高感度レジストを必要とするため, より強 度の強いプラズマ方式やシンクロトロン方式 (SOR) の検討も進められている。またマスク材料も透過性や 強度など解決しなければならない問題をかかえてい る。

次世代の超々 LSI の加工は光でば不可能である，X 線りソグラフィーはいまだ開発途上であるが，X 線 を用いたデバイスの報告は増えており, 数年後の超々 LSI の製造段階では X 線リソグラフィーが威力を発 揮するものと期待する.

\section{文献}

1) H. Nakane, et al.: Polymer Eng. Sci., 23, 1050 (1983)

2) T. Iwayanagi, et al.: Polymer Eng. Sci., 23, 935 (1983)

3) M. Hashimoto, et al. : Preprints of 1st SPSJ International Polymer Conference (Soc. Polymer Sci., Japan), 111 (1984)

4) H.L. Stover, et al.: Proc. SPIE, 470, 22 (1984)

5) B.F. Griffing, et al.: Technical Papers-Regional Technical Conference "Photopolymers PrinciplesProcesses and Materials", 185 (1982)

6) R.D. Coyne, et al.: Solid State Technology, 日本語版, No. 5, 73, No. 6, 91 (1984)

7) E. Reichmanis, et al. : Solid State Technology, 日本語 版, No. 10, 52 (1985)

8) Y. Ohnishi, et al.: Proc. SPIE, 539, 62 (1985)

9) ニコンセミナー (1985)

10) 中瀬 真, 他: 電子材料, No. 6, 47 (1985)

11）加藤忠雄, 他 : Semiconductor World, No. 5, 112 (1985)

12）今村三郎, 他: 半導体・集積回路技術第 15 回シンポジ ウム講演論文集, 24 (1978) 